\title{
Towards Responsible Aggregate Mining in Vietnam
}

\author{
Paulina Schiappacasse ${ }^{1, *}$, Bernhard Müller ${ }^{1,2, *}$ and Le Thuy Linh ${ }^{3,4}$ \\ 1 Faculty of Environmental Sciences, Technische Universität Dresden, 01069 Dresden, Germany \\ 2 Leibniz Institute of Ecological Urban and Regional Development, 01217 Dresden, Germany \\ 3 Faculty of Environmental Sciences, Vietnam National University, Hanoi 10000, Vietnam \\ 4 Dresden Leibniz Graduate School, Technische Universität Dresden, 01069 Dresden, Germany \\ * Correspondence: paulina.schiappacasse@tu-dresden.de (P.S.); bernhard.mueller@tu-dresden.de (B.M.); \\ Tel.: +49-351-463-37891 (P.S.); +49-351-463-37891 (B.M.)
}

Received: 21 June 2019; Accepted: 30 July 2019; Published: 2 August 2019

check for updates

\begin{abstract}
Responsible mining is a new catchword of our times. However, in practice, there seem to be many barriers that hinder the successful implementation of the concept. This is especially true for countries with high urbanization speed, and it is even true for one-party states where its implementation could, in general, be taken for granted as soon as the central government has taken respective decisions and put appropriate stipulations and mechanisms formally in place. On this background, the article deals with barriers and possible solutions regarding responsible mining taking the case of Vietnam, and more especially the Province of Hoa Binh, neighboring Hanoi. Based on a literature review on responsible mining, a set of principles promoting this approach is developed. This is taken as a criteria set for the assessment of respective policies and their implementation on the different levels of authority in Vietnam. Finally, proposals are developed how to advance responsible mining in this case and in other comparable countries.
\end{abstract}

Keywords: responsible mining; aggregates; Hoa Binh; Vietnam; planning and management

\section{Introduction}

It is recognized in literature that during the economic transition from a resource-based to an industry- and services-oriented society, the consumption of aggregates, i.e., stone, sand, and gravel, in the building sector "increases in the same or even a higher degree than the economic performance" [1]. This is the case of Vietnam where an increased urbanization and industrialization process is rapidly creating expanding markets for the use of aggregates, particularly in megacities, such as Ho-Chi-Minh City and the Hanoi Metropolitan Region (HMR).

Internationally, two main concerns have been raised regarding the extraction of aggregates. On the one hand, we have to be aware that aggregates are non-renewable resources. This implies that someday they may not be available for future generations anymore. For example, there is already an international debate about the aggravating shortage of certain types of sand [2,3]. On the other hand, it is obvious that the extraction of aggregates has negative environmental impacts, e.g., caused by inappropriate mining practices, inefficiencies in transportation, excessive energy usage, and extreme landscape alterations [4-8].

In order to address these challenges it is important to acknowledge the economic and social relevance of aggregates. All countries in the world are highly dependent on them as they are the material used to construct and maintain buildings and infrastructure. Thus, there is a high responsibility to develop and manage mineral resources in a way that benefits present needs "without compromising the ability of future generations to meet their own needs" [9]. Therefore, it is increasingly recognized in the international discussion that mineral activities should be conducted in a "responsible" manner, or in other words, by respecting the rights of all stakeholders, including future generations, 
incorporating environmentally friendly practices, as well as establishing and enforcing respective laws and legal stipulations [10-12]. "Responsible mining" has become a catchword of our times. However, unfortunately, little progress concerning the responsible extraction of aggregates has been made worldwide [13-15]. Even in more advanced economies, planning loopholes (like material shortages/oversupplies, and limited access to deposits) reflect the lacking concern for the finite character of aggregates and their role in socio-economic development.

In Vietnam, a fast-growing country that has been experiencing a transition from a communist to a state capitalist system since the mid-1980s [16], the demand for construction material is, and is expected to stay, high. Therefore, there is a need to examine to what extent aggregate mining is carried out in a responsible way, and how institutional, planning, and legal mechanisms for the extraction of aggregates operate in the country. Here, we have to note that Vietnam is a single-party state with a multi-tier political and administrative system consisting of the national level at the top, and-with relevance to the case under discussion in this article-the provincial, (rural) district, and communal levels below. Whereas legislative and executive powers are well divided, the Communist Party of Vietnam plays a decisive role on all levels of government and decision-making. With regard to controlling mineral extraction, authorities on the national and the provincial level, i.e., the Ministry of Natural Resources (MONRE) and the Department of Natural Resources (DONRE), are the most relevant decision-making bodies.

The analysis is particularly relevant at present as significant political emphasis is being placed on promoting a more responsible management of mining resources although the term "responsible mining" is neither directly mentioned nor a common term yet in the country. The Vietnam Mineral Resources Strategy for 2020 with a vision towards 2030 [17] mentions in article 1 that as non-renewable resources, minerals must be managed, protected, exploited, and used rationally, economically, and efficiently to meet the requirements of industrialization and modernization of the country. However, there is a significant gap between environmental policy adoption at the national level and its implementation at the regional and local levels, especially when it concerns stakeholder involvement and participation [18].

On this background, this article poses the following questions: What are the barriers for achieving responsible aggregate mining in fast growing economies, such as Vietnam? Through which short-term strategies and measures can negative environmental impacts be reduced at the local level so that paths towards responsible mining can be paved? Due to the facts that in Vietnam the communist party and the government have a decisive say in development, and that in the literature, the responsibility of companies, in general, is already intensively discussed, this article looks mainly at the role of the state in promoting responsible mining.

In order to answer the research questions, the article is structured into six sections: After this introductory section, the second section provides a review of the ongoing international discussion about responsible mining summarizing a set of principles promoting this approach. The third section focuses on the responsibility of governments in the management of aggregate mining. In the fourth section, the state-of-the-art regarding the management of aggregates in Vietnam is examined following the principles derived from literature in the first section. Taking the Hoa Binh Province as a living laboratory in Vietnam (Figure 1), in the fifth section, we analyze the challenges and options ahead for the implementation of a responsible mining framework that can contribute to the long-term sustainable supply of aggregates. Finally, a section on conclusions is provided at the end.

The article is based on a literature review as well as on an intensive case study in Vietnam, including data analysis, documents analysis, and stakeholder interviews on all levels. Over more than three years, German-Vietnamese teams worked on the management of mineral resource extraction in the Hoa Binh Province. During this period, expert interviews, e.g., with government officials at different levels, entrepreneurs in the mining sector, representatives of media, and other stakeholders, such as persons living in the vicinity of quarries, local farmers, and owners of tourism enterprises, were conducted. Moreover a number of (repeated) site visits, especially at active quarries as well as at 
abandoned mining sites, were carried out. In a series of workshops and conferences, the project results were discussed with stakeholders on all levels of government and with private businessmen.

The article is of high relevance for those interested in responsible mining in general, and in the question of whether and how a fast-growing country with a one-party system like Vietnam can move national goals of protecting and exploiting non-renewable resources efficiently forward towards responsibility and sustainability.

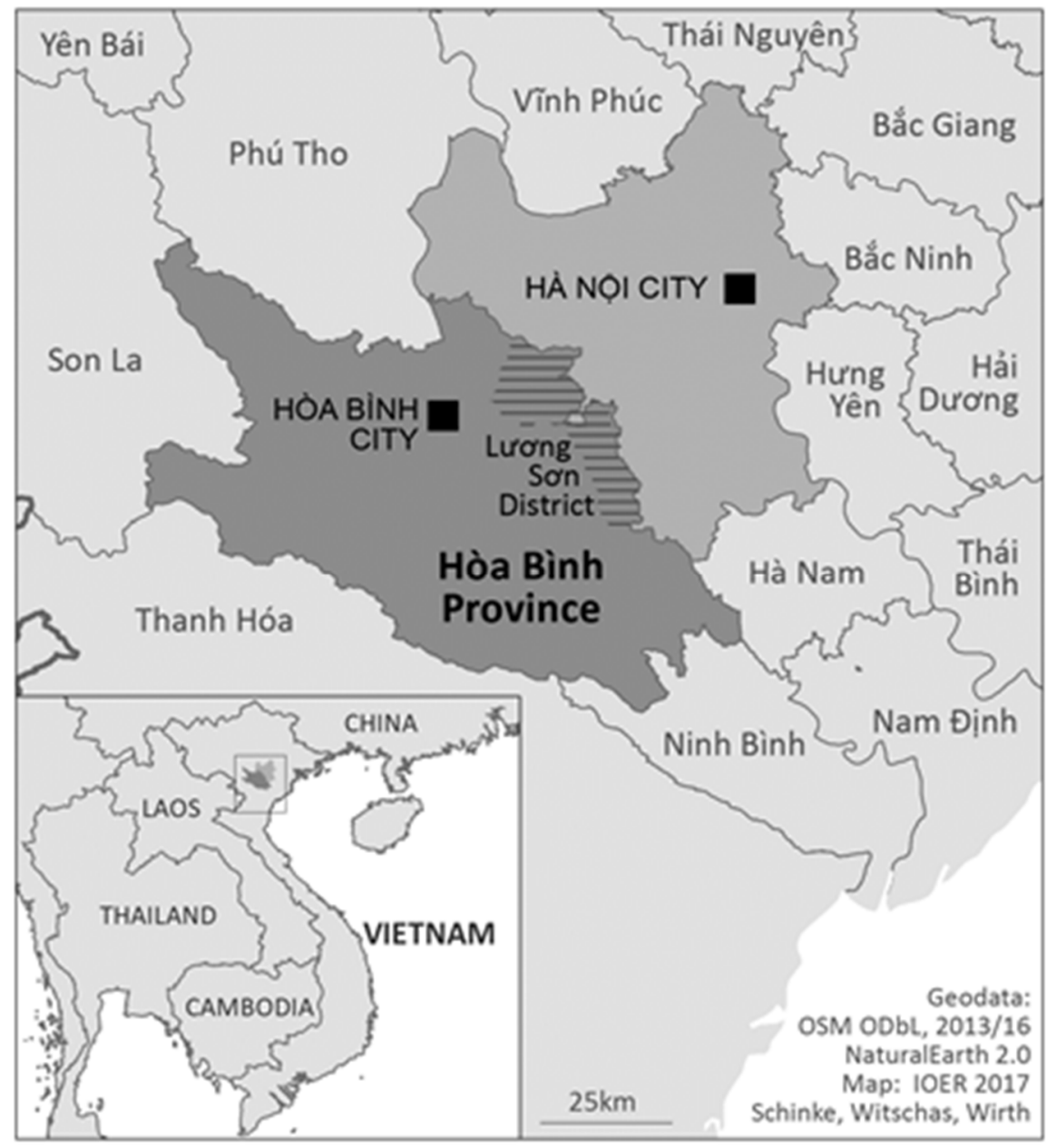

Figure 1. Study area.

\section{From Sustainable Development to Responsible Mining}

The sustainable development goals (SDGs) of the United Nations (UN) do not make direct reference to mining or, even more specific, to the extraction and consumption of aggregates for construction. However, Goal No. 12 may be interpreted at least as an indirect reference to it by requesting "more sustainable patterns of consumption and production" [19]. The UN point out that achieving this goal requires strong national frameworks for sustainable consumption and production, supporting the decoupling of economic growth from natural resource use, especially in a situation in which global figures indicate the contrary, i.e., an increase of the material footprint. Therefore, the UN agreed to achieve the sustainable management and efficient use of natural resources by 2030, and to measure progress by two sets of indicators: (1) The material footprint per capita and per GDP, and (2) the domestic consumption, domestic material consumption per capita, and domestic material consumption per GDP.

On this background, sustainability in mining cannot be understood in the same way like in the case of the extraction of other natural resources [20]. As minerals are not renewable, their extraction will 
lead to extinction, and cannot be sustainable from an environmental point of view. Therefore, there is a shift in the international discussion regarding mineral extraction from "sustainable mining" towards "responsible mining" [10,21,22]. This new perspective can be understood as a "conceptual shift from a singular analysis on mitigation and impacts to a more comprehensive analysis that looks at the wider contribution of the industry and its products" [21]. Responsible mining can be seen as a transparent and environmentally conscious mining activity respecting the rights of all stakeholders, and oriented towards balancing environmental, social, and economic concerns [10,22]. A number of principles specifying the understanding of responsible mining have been identified by different researchers.

Arvanitidis et al. [23] distinguish 12 principles: (1) To identify and engage all actors; (2) to conduct open, inclusive, and continuing dialogue throughout the mining cycle; (3) to engage with communities and stakeholders; (4) to protect the environment and minimize or mitigate impacts; (5) to cooperate closely with regional and local stakeholders; (6) to acknowledge the possibility that, when a project does not meet basic environmental and social criteria, it is not the 'right' outcome; (7) to promote energy savings and increase the use of renewable sources; (8) to manage waste; (9) to plan closure and rehabilitation; (10) to conduct tailor-made and fit-to purpose technology innovation; (11) to provide a safe and healthy environment for all employees; and (12) to educate students on effectively managing mineral resources.

Other authors mention fewer principles. For example, Bice [24] speaks about the necessity (1) to make holistic assessments; (2) to get to community-based agreements; (3) to respect ethical issues in decision-making; (4) to define appropriate boundaries; and (5) to establish good governance. The Initiative for Responsible Mining Assurance [25] highlights the need for (1) business integrity; (2) social responsibility; (3) environmental responsibility; (4) taking stake in reclamation and closure; and (5) establishing modern management systems. Goodland [10] mentions (1) social and environmental assessment; (2) transparency vs. secrecy; (3) acceptance by stakeholders; (4) food production vs. questionable mining; (5) compliance with international standards; (6) prequalification or certification of potential mining permit seekers; (7) insurance and performance bonds; and (8) royalties, taxes, and bonds. Finally, Miranda et al. [22] propose (1) to carefully decide whether mining is the appropriate land use; (2) to ensure environmentally responsible mining; (3) to ensure that mine development results in benefits to workers and affected communities; and (4) to ensure good governance.

The challenges for meeting these principles are complex and differ according to the type of mined material, the scale of production, the type of legislation, and the legitimation of stakeholders, and there is a risk of "greenwashing" business activities. Whereas, there is an intensive discussion on the role of companies to make mining more responsible, the function of governments is, to a far lesser extent, dealt with in literature. Construction aggregates must be considered strategic minerals. Given any society's dependence on their provision and the necessity to use these minerals in a sustainable manner for the wellbeing of future generations [26,27], governments responsibility in aggregates management is indisputable. As D'Esposito [28] argued almost 20 years ago, the international discussion still focuses on technical issues of how to mine rather than the larger issues of whether, and where to mine, and whom to involve in which way in decision-making.

Most existing mineral policies in industrialized countries do not give aggregates a strategic character as critical raw materials. The European Aggregates Association has long criticized this negligence and the necessity to develop a raw material strategy [29]. Although there is not yet a common European strategy, a Raw Material Initiative was issued in 2008 [30], recognizing aggregates as an essential component of the material inputs into the construction industry.

\section{A Framework for Addressing the Responsibility of Governments for the Extraction of Aggregates}

Evidently, governments follow different approaches to ensure a sustained supply of aggregates, influencing the way mining activities are conducted. They reach from a market-driven approach, where governments, mainly in less economically developed countries, only have a passive influence on 
the market, e.g., regarding access, to a strong government-driven approach where authorities pursue an active policy guiding the strategic development [1].

In economically less developed countries, companies can be granted mineral rights in different ways. On the one hand, countries with a well-developed legal system, such as Vietnam, Chile, and Zambia, grant mining licenses through frameworks that regulate the rights and obligations of the state and the respective companies [31]. However, in Vietnam, despite this legal backup, progress in achieving good mining practices has been slow due to insufficient and inconsistent local implementation of the legal framework [32].

On the other hand, in countries with weak legal frameworks, such as The Philippines, Burkina Faso, and Mongolia among others, governments usually grant mineral rights to private companies through individual negotiations. Although there are wide variations regarding types of contracts, governments usually end up with poorly negotiated deals containing limited benefits to local communities [31]. For instance in India, the lack of regulatory policies, environmental impact assessments, and monitoring systems have led to indiscriminate sand mining triggering severe damage to the environment [33].

On the contrary, industrialized countries, such as Sweden and The Netherlands, emphasize environmental protection in their legislation, for example through the promotion of a reduced use of minerals and encouraging material recycling. Austria developed a raw materials plan, of which the main objective is to protect the access to mineral deposits [34]. In Germany, regional planning identifies, in cooperation with all concerned stakeholders, so-called priority areas for gravel and sand mining, giving them a specially protected status.

Based on the literature review presented in Section 2 of this article, the roles and tasks of governments to safeguard a responsible management of aggregates can be summarized in eight principles. In short, they are: (1) Define policy statements (objectives and standards) that act as guidance for industry development; (2) promote land use planning to identify and establish deposits, reserve areas, and buffer zones to prevent land use conflicts with other sectors; (3) establish a regulatory process for granting licenses, controlling, and monitoring environmental impacts; (4) promote transparency in taxation, fee calculation, and revenue allocation; (5) acknowledge, regulate, and assess environmental and socio-economic impacts, defining clear compensation methods; (6) establish the obligation to present, finance, and implement a post-mining activity plan; (7) promote the use of clean technologies and recycled aggregates; and (8) stakeholder involvement (as a transversal principle). These principles are described with more detail in the following paragraphs.

First, and despite its relevance, the development of mineral policies is not common worldwide, and if they exist, they hardly recognize the different types of minerals and the stages of the mining cycle [14,34]. For example, according to an EU Report from 2014, not even all EU Member States have a national mineral aggregate policy in place, and those policies that have been adopted are not necessary aligned with sectoral needs and priorities [35]. Additionally, mineral issues are often allocated at lower priority than other national strategic objectives [34].

Second, land use plans are crucial instruments to identify where and under what conditions aggregate extraction is allowed and/or prohibited. Plans are based on the consideration of geological information as well as on statistics regarding production and consumption patterns. Details are negotiated among the concerned stakeholders in an open participation discourse. They are essential elements for short- and long-term mineral planning.

Third, legal and administrative frameworks are necessary to develop and enforce standards for mining practices and operations management. An "effective system" is characterized by a clear regulatory framework on how licenses are issued, monitored, and terminated, including well-defined institutional responsibilities and procedures based on established criteria [36]. The administrative framework is relevant to understand the different horizontal and vertical government levels involved in the granting of licenses, e.g., by mining authorities, geological agencies, regional governments, local authorities, and environmental agencies. Besides the problems associated with overlapping 
competences, inconsistencies, duration, and bureaucracy, there is an ongoing discussion regarding the pertinence and effectiveness of decentralizing the process for granting mining licenses.

Fourth, the tax structure represents an important policy issue as it influences investment behavior and reflects country sustainable strategy. For instance, a high mining levy might be an incentive to reduce use and consumption. Revenues collected by the government might be distributed in different ways involving central, regional, and local governments.

Fifth, during the last decades, many legal frameworks have incorporated the requirement to submit integrated social, economic, and environmental assessments, which describe risks and impacts together with mitigation and management measures.

Sixth, mining legacy can persist long after closing aggregate extraction. Therefore, a legal framework should clarify issues relating to the closure of mines as part of the mining approval process [37].

Seventh, although recycled aggregates are increasingly seen as a valuable alternative especially in Europe, they are still not conventionally and worldwide used in the construction industry. A recent trend is to invest a proportion of the revenues in promoting innovation and cleaner production technologies. For example, this is the case regarding the aggregate levy in the United Kingdom [38].

Eighth, and finally, stakeholders' interests, responsibilities, and rights, i.e., those of entrepreneurs, communities, individuals, and the government, need to be included in all principles. In many countries, public participation has become obligatory at all stages of the mining assessment.

\section{The Extraction of Aggregates in Vietnam-Steps Towards Responsible Mining}

Promoting industrialization and modernization are among the major goals of the Vietnamese Central Government [39]. This is accompanied by fast urban growth. According to the Vietnam Urban Development Vision 2025-2050 [40], the proportion of urban population is expected to grow from 38\% in 2015 to $45 \%$ by 2020 and $50 \%$ by 2025 . The main driving forces behind fast urbanization are public investment in infrastructure and the opening up of land to leaseholds entitlement [41]. These driving forces put housing and infrastructure development in all urban areas under enormous pressure, causing an unprecedented demand for aggregates in the construction sector. On this background, it becomes vital for the urban sustainability discussion and the issue of responsible mining in Vietnam to have a closer look at how aggregates are managed in the country, and what barriers for achieving responsible mining exist. The eight principles described in Section 3 of this article provide the main framework for the analysis.

(1) Policy guidance: In Vietnam, mineral planning is undertaken in a rather comprehensive way at a high administrative level. The Mineral Law (article 4) and the Mineral Resources Strategy to 2020-2030 (article 1) promote the management, environmental protection, and the efficient use of minerals to meet the requirements of industrialization [17,42]. Even more, the Mineral Strategy, states that the exploitation of minerals for construction must follow strict rules of labor safety as well as landscape and environment protection. For example, regarding the latter, the exploitation at hill sides along national highways is not encouraged.

Specific resolutions have been issued to implement these principles promoting responsible management at grassroots levels [43]. The country also has a master plan on basic geological survey of minerals through 2020-2030 [44], elaborated by MONRE, and a master plan for the exploration, mining, processing, and use of minerals as construction materials [45] issued by the Ministry of Construction (MOC). Such master plans are dynamic long-term planning documents that provide a conceptual layout to guide future growth and development [46]. However, the two documents are very general as they do not show spatial information regarding the distribution of aggregates nor do they contain reliable data on reserves and the expected demand.

Moreover, the Mineral Law (article 10) states that national master plans for the exploitation and use of each kind of group of minerals to be used as construction materials, including sand, gravel, and stone, 
will be developed. However, until now they have not been produced and only one master plan (for the exploitation and use of limestone) is available due to its strategic importance for cement production.

The reasons behind these planning shortcomings in aggregates are manifold: First, aggregates are perceived as an abundant and low-unit value commodity and their extraction is not monitored; second, the government does not invest in assessing the availability and quality of sources of aggregates transferring this responsibility to private investors; and third, aggregates fall under the responsibility of two authorities, which do not always coordinate their activities: The MOC is in charge of minerals for construction (including aggregates) and urban development (construction planning), and the MONRE is responsible for land use planning and for regulating and assessing the socio-economic and environmental impacts of mining activities.

(2) Land use and construction planning: Socio-economic and sectoral planning are highly centralized and use a top-down approach imposing methodological and practical perspectives [47]. The State owns and controls the land, it assigns the main general purpose of use (e.g., agriculture, forestry, non-agricultural, residential, industrial, and office use), and decides who has the right to use it and for how long [48]. Thus, land use plans at national, provincial, and district levels tend to be based on political targets rather than on local demand or local and regional spatial challenges. Urban planning instruments, i.e., "construction planning", at different spatial levels (national, provincial) reinforce the national message of modernization promoting urbanization. They give the extension of existing residential areas, the development of new areas, and the provision of industrial zones high priority. They include population projections, land purpose-related rights of way, floor area ratios, and building heights. As a result, urban planning tends to pursue a supply driven rather than a demand-driven approach [48]. Socio-economic realities and local necessities are not incorporated in planning perspectives. Summing up, sectoral planning is highly fragmented and without vertical and horizontal coordination among administrative levels. Additionally, plans run on different schedules using inconsistent data and projections [41].

(3) Granting licenses: For starting a mining project in Vietnam two licenses, for exploration and for mining (encompassing mineral processing) must be obtained [42].The Provincial People's Committee (PPCs) is the responsible authority to issue licenses to explore and mine minerals for construction while MONRE is the authority in charge of all other types of minerals. To obtain a license to mine aggregates, companies have to present a mining investment project (in conformity with national and provincial master plans for exploration, mining, processing, and use of minerals for construction materials), an environmental protection plan (EPP), or an environmental impact assessment study (EIA), and they need to justify a financial capital, which has to be at least equal to $30 \%$ of the total investment for implementation. Individuals or companies that mine aggregates are not required to apply for licenses when mining is conducted within the premises of an approved construction investment project.

(4) Taxation and revenue allocation: Once a company obtains a license for mining aggregates, it has to pay different fees and taxes. Though Vietnam decentralized the allocation of mining licenses in 2005, this process has been accompanied only partially by a fiscal decentralization. Major taxes are set by the central government (corporate income tax and VAT) and minor ones by the provinces. The central government empowers the provincial level (PPCs) to collect taxes and fees from mining companies. However, revenue sharing does prioritize those local communities where mining takes place and where income is generated. Moreover, there is a lack of transparency regarding sectoral revenue sharing. For instance, the Law on Environmental Protection (2014) establishes that collected environmental protection fees shall be used for environmental protection activities [49]. However, the use and allocation of the funds are rather unclear resulting in people blaming companies for the environmental impacts even if they have fulfilled the financial obligations for protecting the environment, and have paid a deposit for environmental rehabilitation and restauration before conducting mining activities [42].

(5) Environmental and socio-economic impacts: Following the Mineral and Environmental Protection Laws, companies intending to undertake mining activities in Vietnam must submit an EIA 
or an EPP depending on the size of the investment project for approval. The EIA content shall allow the identification and assessment of all potential environmental impacts associated to the mining process of aggregates. The reviewing and appraisal process is clearly described in the legislation. The PPCs assess and approve the respective reports. Likewise, companies must present an environmental rehabilitation plan in order to leave mining sites in a well-organized state after mining stops, and to prevent emergencies. In this case, the environmental protection-Fee declared on a monthly or an annual basis - is supposed to be used to prevent and mitigate impacts, to remedy degradation, and to keep sanitation. However, as aggregates have a low unit price, the fee is rather low and does not reflect adverse landscape impacts. The Vietnamese government does not only incorporates EIA as a management tool for approving mining projects. The rights of local people living in mining areas are as well legally safeguarded covering aspects such as compensation in case of displacement, the development of an investment plan for localities and the prioritization of local employment [50]. However, in practice, many localities did not implement these decisions and no official information is available about its current status [51].

(6) Post mining activities: Before conducting mining activities, companies are required to pay a DERR (Deposit of Environmental Reclamation) in order to financially secure post-mining restauration. Solutions and costs must be identified in the investment project and the EIA reports and the environmental protection commitments must be approved by competent agencies. After completing rehabilitation activities, exploiters shall send dossiers (including community consultation) requesting certification of the completion of activities to MONRE or DONRE. In cases where rehabilitation activities are not appropriate, competent agencies shall decide on the use of the deposits for environmental restauration and select the specific areas to restore the environment in accordance to law. However, reports show that rehabilitation activities after mining have not been implemented in many localities [32].

(7) Clean technologies and recycling: According to the Vietnamese Mineral Law, mining companies are required to use environmentally friendly technologies, to apply solutions to prevent and mitigate adverse impacts, and to upgrade and restore the environment [42]. However, until now, the promotion of clean technologies and recycling as well as the restoration of the environment are still in infant stages.

(8) Stakeholder involvement: While the Mineral Law has only one article (article 5) addressing the rights of people living in areas where minerals are, almost a complete chapter (Chapter 3 ) regulates the responsibilities of different ministries and people's committees at different levels in relation to mining activities [42]. Additionally, almost all central legal documents defining responsibilities mention that the opinions from different ministries and provincial authorities must be collected (e.g., article 15, Mineral Law). This unbalanced consideration between the roles of inhabitants and government authorities shows that devolution in decision making stopped at the provincial level and did not empower districts, communes, and individual inhabitants sufficiently. Public participation and consultation on land use planning is legally required [52]. It is supposed to be conducted by MONRE and the PPCs websites, and through organized meetings, direct consultation, and the publication of plans. However, documents are not available for the public and there is no involvement of districts, communes, and inhabitants in the preparation of master plans [53]. Additionally, during the EIA process, the opinions of the people's committee of the respective commune and of other representatives of the commune where the project is implemented have to be considered [49]. However, international reports on the environmental situation describe public involvement as a mere "formalism" because consulting the community is often skipped [51].

\section{Challenges for Planning the Extraction of Aggregates at Provincial Level: Hoa Binh as an Example}

The efforts of the Vietnamese government for institutionalizing responsible mining during the last decade are evident. However, important gaps still remain between the national expectations, which are, for example, materialized in concrete laws, regulations, and guidelines, and the real implementation at the district and communal level. In 2015, the Central Government admitted the necessity to reorganize 
and strengthen the state management for the exploitation of minerals, taking the short- and long-term necessities to achieve economic development, social efficiency, and environmental protection into consideration [43]. The mining sector shares a common gap reflected mainly in the capacity, skills, and independence of the private and public practitioners involved in extraction activities and in the effectiveness of stakeholders' engagement in the decision-making process [54].

In the Greater Hanoi area, the population stands at more than 7 million [55], and following the Hanoi Capital Construction Master Plan, an enormous number of investments in the construction sector (i.e., residential and commercial buildings as well as public infrastructure) are expected until 2030 and beyond. Due to its proximity to the capital region, aggregates produced in the Hoa Binh Province, mainly in the Luong Son district, supply part of the current demand of Hanoi's construction industry (Figure 1).

We chose the Hoa Binh Province as a research laboratory to analyze the challenges ahead to implement a comprehensive planning system for the long-term supply of aggregates. As part of field activities, 35 face-to-face, semi-structured interviews were conducted during November 2016. The sample included provincial districts and commune government officers, environmental inspectors, environmental private consultants, politicians, entrepreneurs, representatives of local associations (farmers and aggregates), and local population living around the extraction sites. It must be noted that almost all interviews were (and had to be) organized through the provincial government (DONRE). Although government officials did not interfere or stay during the interviews, the necessity to rely on government support to contact aggregates' stakeholders reflects the strong authoritarian (top-down) regime of the One-Party Vietnamese political system, discussed further below. The most-frequently mentioned issues across interviews were clustered and supplemented by direct observations and literature analysis. Following the strategic principles for responsible mining developed above, the following main challenges in Hoa Binh Province can be mentioned here.

(1) Policy guidance: There is rather limited independent policy guidance on the provincial level. This is due to the fact that provinces are eager to fulfil the expectations of the national government regarding production figures and the provision of resources which are strategic for economic growth. This leaves very little room for own priority setting or a more restrictive extraction policy and guidance. Moreover, there are weak communication, cooperation, and coordination structures between provincial and communal departments as well as between the public and private sector and the community.

(2) Land use and construction planning: Land use and construction planning exists. However, it fails to include mining activities, like aggregates mining, in a comprehensive way, and plans are not open to the public. Extraction sites are identified by geographical coordinates, though, they are not geo-referenced in a map. Thus, there is a weak basis for decision-taking regarding the granting of licenses, and the assessment of environmental and socio-economic effects of mining.

(3) Granting licenses: The decentralization of licensing aggregate mining to the provincial level in Vietnam in 2005 has led to a sharp increase of licenses. For example, during the first four years of provincial responsibility (2005-2008), nearly 3900 mining licenses were granted by the provincial governments in Vietnam through their respective departments (DONRE), while during 13 years of preceding and partly overlapping central government responsibility (1996-2008), only 928 projects were licensed by the responsible national ministry (MONRE) [56]. Licensing processes are well regulated and conducted according to well established procedures. However, due to the weak cooperation between the different provincial departments (for natural resources, for construction, for taxes, and for land use) involved, there is unclear information regarding the number of granted licenses, businesses in operation, expired licenses, and interrupted or terminated quarrying activities. This makes a follow-up and monitoring of aggregates mining extremely difficult. Moreover, decision making in general, the designation of mining sites, the approval of mining licenses, as well as monitoring, surveillance, and enforcement are weak because the provincial government either does not have adequate information or appropriate human resources or technical capacity for carrying out these functions in a proper way. 
(4) Taxation and revenue collection: The collection of taxes and fees plays a major role in the provincial government, and in its responsible departments. Nevertheless, the collection of environmental taxes and fees (e.g., natural resource tax, environmental protection fee) does not lead to local investment in environmental improvements where mines are allocated. Despite being required by law, the use and allocation of revenues is unclear, resulting in communities blaming companies and companies blaming the government for inefficient management.

(5) Environmental and socio-economic impacts: Companies have to provide an EIA report before mining licenses are granted, and they also have to submit annual reports, which include information about the environment. However, there are often differences between the approved operation and reality. Moreover, although there are rather strict regulations regarding environmental protection and safety at work, they seem to be seldom implemented. According to results of Oswald et al., the violation of respective regulations on environmental protection and labor safety is rather common [57]. Blasting is an issue of special concern for the communities due to noise, vibrations, and flying rocks, often causing property damage and injury. In addition to insufficient staff to follow up the wide set of regulations, many quarries are not controlled simply because there is no map available with the exact location of the extraction sites.

(6) Post-mining activities: Since 2014, regulations concerning the rehabilitation of mining sites after mining ends have been introduced [49]. Companies even have to pay a certain deposit, which is supposed to be used for rehabilitation activities (DERR). Although there is no experience with the application of these regulations yet, it can be assumed that the rehabilitation fee is not high enough to assure rehabilitation in order to facilitate new land uses (e.g., recreation, agriculture, forestry), which could be carried out in a safe manner. Moreover, there are already abandoned open pits in the hills and along river valleys from older mining activities, which had not been rehabilitated and transformed. In some cases, this has resulted in illegal landfill sites. Finally, also, extraction sites with still-valid mining licenses have been abandoned, e.g., due to a lack of capital or technical capacities, without informing the local or provincial authorities. As the communication channels between the different local and provincial institutions are rather weak, such sites often remain undiscovered for a long time, rendering it impossible to make the license holder liable for damage or rehabilitation.

(7) Clean technologies and recycling: Inadequate extraction techniques generate landscape alteration, ground vibration, and dust [57]. Though the number of granted mining licenses has considerably increased after decentralizing decision-making about granting licenses for aggregate mining to the provincial level in 2005, the private investment in new extraction technology has been limited. Except for the exploitation of limestone for cement production, aggregates are mined with rather old and outdated technology. Interviewed entrepreneurs argue that the business profit is not enough to invest in new technologies and no governmental financial incentive or training activity (e.g., regarding blasting techniques) have supported them in these aspects. Thus, the small size of the existing enterprises and their scattered distribution matter regarding the introduction of clean technologies and up-to-date production technologies and techniques. However, interviews with mining companies have revealed that entrepreneurs are also not aware of the national government's efforts to promote the use of environmentally friendly technologies.

(8) Stakeholder involvement: There is only a low level of local participation in the decision-making process regarding planning and licensing of aggregate mining activities in the province. This is due to weaknesses of the regulatory framework, and to the lack of awareness and expertise among the communities, e.g., regarding EIA purposes. Multiple conflicts among stakeholders can be identified, including the concern of communities and the population regarding environmental impacts of mining, disputes over the use and occupation of land, as well as the lack of more detailed knowledge and information about mining activities, especially related to blasting. Additionally, due to the lack of related framework regulations, in the case of negotiating compensation measures (e.g., relocation of housing compounds and losses in agricultural production), affected persons have to individually discuss these issues directly with the mining companies without any assistance from the local government or 
concerned civic organizations. Although communal representatives and members of the Vietnamese Fatherland Front, the party-aligned umbrella of mass movements of the country established to formally represent and protect the rights and interests of the population, seem to be often invited by companies to participate in negotiations, such local stakeholders usually do not take sides in cases of conflict.

There are many proposals and instruments related to how planning is able to deal with land use conflicts associated with the challenges described above [15,58,59]. They range from considering the "rights" and "powers" of the involved actors to the implementation of "interest-based" perspectives. However, in Vietnam, due to the One-Party-State-related strong administrative intervention from above, there are limited possibilities to apply such instruments addressing land use conflicts. The political and social context in which planning for aggregates mining takes place differs significantly from other realities. First, the One-Party-State has absolute authority over the management of natural resources. Second, it keeps strong control of entrepreneurs as well as of community associations and non-governmental associations [60]. As a result, and third, what the occidental world calls "civil society", is defined by Jeong [61] in Vietnam as "state corporatism". This is a system where the different stakeholders (Association of Aggregates Entrepreneurs and the Farmer's Union) engage with the One-Party-State institutions, representing their interests at local level. Therefore, stakeholder participation and the settling of disputes and conflicts of interest between different parties sometimes seems less open and transparent, and those who do not have or do not want to have access to the official conflict management system have to settle disputes on an individual level.

\section{Conclusions}

Although mining, and especially mining of aggregates for construction, is not explicitly mentioned in the SDGs of the United Nations, reference can be made to Goal 12. Nevertheless, and in order to avoid misunderstanding, the discussion about sustainable development has shifted in the case of mining towards responsible mining. We have defined eight features to characterize what responsible mining means in the concrete context of construction aggregates. They are related to policy guidance, land use and construction planning, the process of granting licenses, taxation and revenue collection, environmental and socio-economic impacts, the facilitation of post-mining activities, clean technologies and recycling, and stakeholder involvement. These eight principles have been taken to analyze the mining of aggregates in the fast-growing capital region of Hanoi, and especially in a neighboring province to the capital, Hoa Binh, which dealt as a research "laboratory".

As a result, we could see that there are major deficiencies regarding a clear national and provincial planning guidance for the extraction of aggregates. They negatively influence the planning and operation of mining activities, and the transparency and effectiveness of the operative processes at local level. For example, at present, in the province, there is no clarity about the specific allocation criteria for granting licenses, the number of operating licenses, the location of existing quarries, the tons of material extracted and demanded, and the places where material can be mined or where mining is or should be banned.

Although Vietnam is a country where the extraction of natural resources remains under state control, the extraction of aggregates is controlled by market fluctuations. As a consequence, planning loopholes become evident, such as shortages or oversupply of materials, limited access to deposits, and the increase of illegal activities. These loopholes reflect the lack of awareness on the finite character of the resources and on their significant role in fulfilling socio-economic development. It is needless to say that deficient planning and monitoring, limited administrative capacities, and severe limitations regarding post-mining land-recovery are leading to heavy environmental disturbance and destruction of (formerly) spectacular landscapes with high biodiversity and recreational potential without significantly contributing to the improvement of the wellbeing of the local population. Taking up the discussion about urban-hinterland relations, we can state that while the advantages of aggregates mining are clearly on the side of Hanoi, the neighboring province of Hoa Binh is left with many challenges to be solved in the future. 
These results are surprising if compared with the rather well-defined institutional setup regarding the mining sector where many important features of responsible mining have at least in part been integrated into laws, regulations, and organizational provisions. What is obviously lacking behind, is their consistent implementation on the ground. Here, we see vast potential for further improvement, which can be highlighted by the following examples.

Policy guidance can be streamlined in order to avoid inconsistencies and misinterpretation. For example, this would need a better balance between environmentally oriented intentions of the government to set up high international technological standards for aggregate mining and promoting clean technologies, and society oriented efforts to open up new business opportunities for as many small entrepreneurs as possible, even including those who may have severe difficulties to comply with the respective standards. Clear guidelines combined with adequate capacities at the provincial level could also facilitate more effective monitoring and control of mining activities.

On the provincial level, regional planning should be strengthened. It should be based on appropriate and transparent knowledge and information about local conditions and requirements as well as current and future market needs. Regional planning should take much more responsibility than in the past to organize a balance between differing interests by involving all stakeholders in planning and consultation processes, including local communes and the population living in areas, which are affected by mining activities. According to interviews on the local level, the willingness and the institutional preconditions for broader communication and consultation exist. What is needed besides capacity building and adequate resources is a changed understanding of planning, recognizing it as a participatory tool, and the conviction that not only the societal mass organizations, but also individuals, with all their local knowledge and aspirations, should be directly involved in planning processes in order to achieve more solid and lasting results.

Thus, regional planning could become a powerful instrument if pursued effectively, leading to coordination, cooperation, and convergence between stakeholders with different interests. Besides the definition of guiding principles for mining, regional planning must include where, when, and how the extraction of aggregates for construction should take place and what is expected after the exploitation works and closure of mines. Such a regional plan has also to consider-in the case of the Province-the material demands from neighboring major cities. Therefore, inter-regional coordination and cooperation is necessary. The national government has many opportunities to support such processes, which may lead to stronger environmental protection through responsible mining.

Author Contributions: Conceptualization, P.S. and B.M.; methodology, P.S.; validation, P.S., B.M. and L.T.L.; formal analysis, P.S. and B.M.; investigation, P.S., B.M. and L.T.L.; writing-original draft preparation, P.S. and B.M.; writing - review and editing, P.S. and B.M.; project administration, B.M.

Funding: This research was funded by the German Federal Ministry for Education and Research (BMBF), grant number 033r122A and 033R122B.

Acknowledgments: To Leibniz Institute of Ecological Urban and Regional Development (IÖR) for supporting with geo-visualization.

Conflicts of Interest: The authors declare no conflict of interest.

\section{References}

1. Tiess, G.; Kriz, A. Aggregate Resources Policies in Europe. Int. J. Environ. Prot. 2011, 1, 54-61. [CrossRef]

2. Torres, A.; Brandt, J.; Lear, K.; Liu, J. A looming tragedy of the sand commons. Science 2017, 357, $970-971$. [CrossRef] [PubMed]

3. Brown, G. A Global Sand Shortage could Cause Damaging Effects to our Rapidly Urbanizing World; Business Insider: Berlin, Germany, 2019.

4. European Commission. Promoting Sustainable Development in the EU non Energy Extractive Industry; Comission of the European Communities: Brusels, Belgium, 2000; p. 20.

5. Drew, L.; Langer, W.; Sachs, J. Environmentalism and Natural Aggregate Mining. Nat. Resour. Res. 2002, 11, 19-28. [CrossRef] 
6. Blodgett, S. Environmental Impacts of Aggregate and Stone Mining; Chambers, D., Ed.; Center for Science in Public Participation: Cerrillos, NM, USA, 2004; p. 7.

7. Langer, W.; Drew, L.; Sachs, J. Aggregate and the Environment. In Environmental Awareness; American Geological Institute: Alexander, VA, USA, 2004; p. 68.

8. Poulin, R.; Pakalnis, R.; Sinding, K. Aggregate Resources: Production and Environmental Constraints. Environ. Geol. 1994, 23, 221-227. [CrossRef]

9. World Commission on Environment and Development. Our Common Future; United Nations: New York, NY, USA, 1987; p. 247.

10. Goodland, R. Responsible Mining: The Key to Profitable Resource Development. Sustainability 2012, 4, 2099-2126. [CrossRef]

11. Mudd, G. Sustainable Mining-An oxymoron? Chem. Eng. 2007, 798, 27-29.

12. Nooten, G. Sustainable Development and Nonrenewable Resources-A Multilateral Perspective, in Deposit Modelling, Mineral Resource Assesment and Sustainable Development; Briskey, J., Schulz, K., Eds.; International Union of Geological Sciences: Rio de Janeiro, Brazil, 2007; pp. 35-40.

13. Miliutenko, S. Aggregate Provision and Sustainability Issues in Selected European Cities around the Baltic Sea in KTH, Department of Urban Planning and Environment; Royal Institute of Technology Sweden: Stockholm, Sweden, 2009; p. 82.

14. University of Loeben. Planning Policies and Permitting Procedures to Ensure the Sustainable Supply of Aggregates in Europe; Department of Mineral Resources and Petroleum Engineering, University of Leoben: Leoben, Austria, 2010; p. 53.

15. Langer, W.H.; Tucker, M.L. Specification Aggregate Quarry Expansion-A Case Study Demonstrating Sustainable Man-Agement of Aggregate Resources; U.S. Geological Survey: Liston, VA, USA, 2003.

16. Cling, J.-P.; Razafindrakoto, M.; Roubaud, F. Is the World Bank compatible with the "Socialist-oriented market economy"? A political economy approach applied to the case of Vietnam. Rev. Régul. 2013, 13. Available online: https://ideas.repec.org/a/rvr/journl/201310081.html (accessed on 21 June 2019).

17. Government of the Socialist Republic of Vietnam. Mineral Resources Strategy to 2020-2030 in Decision 2427/2011/QD-TTg; Office, P.M., Ed.; Socialist Republic of Vietnam: Hanoi, Vietnam, 2011.

18. Acuña-Alfaro, J.; Tran, A. Vietnam's Public Bureaucracy and Implementation of two ASEAN Policies. In He Role of the Public Bureaucracy in Policy Implementation in Five ASEAN Countries; Quah, J., Ed.; Cambridge University Press: Cambridge, UK, 2016; pp. 1-72.

19. United Nations. Transforming Our World: the 2030 Agenda for Sustainable Development; United Nations: New York, NW, USA, 2015; p. 35.

20. Solar, S.; Shields, D.; Miller, M. Mineral Policy in the Era of Sustainable Development: Historical context and future content. RMZ-Mater. Geoenviron. 2009, 56, 304-321.

21. International Council on Mining \& Metals. Mining's Contribution to Susutainable Development-An Overview; ICCM: London, UK, 2012; p. 8.

22. Miranda, M.; Chambers, D.; Coumans, C. Framework for Responsible Mining: A Guide to Evolving Standards (CSP). World Resource Institute (WRI); Center for Science in Public Participation, 2005; p. 155. Available online: http://www.frameworkforresponsiblemining.org/ (accessed on 21 June 2019).

23. Arvanitidis, N.; Boon, J.; Nurmi, P.; Di Capua, G. White Paper on Responsible Mining; International Association for Promoting Geoethics (IAPG): Rome, Italy, 2017; p. 5.

24. Bice, S. Responsible Mining: Key Principles for Industry Integrity; Routledge: Apenton, UK, 2016.

25. Initiative for Responsible Mining Assurance. IRMA Standard for Responsible Mining; Initiative for Responsible Mining (IRMA): Washington, DC, USA, 2018; p. 202.

26. McEvoy, D.; Ravetz, J.; Handley, J. Managing the Flow of Construction Materials in the North West Region of England. A Mass Balance Approach. J. Ind. Ecol. 2004, 8, 121-140. [CrossRef]

27. West, T.; Cho, K. Environmental and Social Issues Associated with Aggregate Extraction: The Lafayette-West Lafayette, Indiana, and Other Examples, USA; IAEG: Nottingham, UK, 2006; p. 5.

28. D'Esposito, S. Is Mining Sustainable? Corp. Ethics Monit. 2000, 12, 1-3.

29. European Aggregates Association. Sustainable Industry for a Sustainable Europe; UEPG, Ed.; UEPG: Brussels, Belgium, 2012.

30. European Commission. The Raw Materials Initiative-Meeting Our Critical Needs for Growth and Jobs in Europe; European Commission: Brussels, Belgium, 2008; p. 14. 
31. Kienzler, D.; Toledano, P.; Thomashausen, S.; Szoke-Burke, S. Natural Resource Contracts as a Tool for Managing the Mining Sector; Federal Ministry for Economic Cooperation and Development: Hannover, Germany, 2015; p. 69.

32. VVCI-CODE. The Extractive Industries Transparency Initiative and the Implementation Perspective of Vietnam; Vietnam Chamber of Commerce and Industry (VCCI) and Consultancy on Development (CODE): Hanoi, Vietnam, 2011; p. 76.

33. Chilamkurthy, K.; Marckson, A.V.; Chopperla, S.T.; Santhanam, M. A Statistical Overview of Sand Demand in Asia and Europe. In Proceedings of the International Conference UKIERE CTMC'16, Goa, India, June 2016; p. 15.

34. Wagner, H.; Tiess, G.; Solar, S.; Nielsen, K. Mineral Planning Policies in Europe. RMZ Mater. Geoenviron. 2006, 52, 607-620.

35. European Union. Report on Critical Raw Materials for the EU; European Union: New York, NY, USA, 2014; p. 41.

36. Venugopal, V. Assessing Mineral Licensing in a Decentralized Context: The Case of Indonesia. In Policy Paper; Natural Resource Governance Institute: New York, NY, USA, 2014.

37. World Bank. It's Not Over When It's Over: Mine Closure Around the World; International Finance Corporation, World Bank: Washington, DC, USA, 2002; p. 28.

38. Ettlinger, S. Aggregates Levy in the United Kingdom; Institute for European Environmnetal Policy: London, UK, 2017.

39. Government of the Socialist Republic of Vietnam. Socio-economic Development Strategy of Vietnam for 2011-2020. In Resolution 142/2016/QH1; Assembly, N., Ed.; Socialist Republic of Vietnam: Hanoi, Vietnam, 2016.

40. Government of the Socialist Republic of Vietnam. Vision of General Planning for Vietnam Urban Development 2025-2050. In Decision 445/2009/QD-TTg; Office, P.M., Ed.; Socialist Republic of Vietnam: Hanoi, Vietnam, 2009.

41. World Bank. Vietnam Urbanization Review; Technical Assistance Report; Bank, W., Ed.; The World Bank in Vietnam: Hanoi, Vietnam, 2011; p. 263.

42. Government of the Socialist Republic of Vietnam. Mineral Law. In 60/2010/QH12; Assembly, N., Ed.; Government of the Socialist Republic of Vietnam: Hanoi, Vietnam, 2010.

43. Government of the Socialist Republic of Vietnam. Directive on the enhancement of the effect of the legislations on Minerals. In Directive 03/2015/CT-TTG; Office, P.M., Ed.; Government of the Socialist Republic of Vietnam: Hanoi, Vietnam, 2015.

44. Government of the Socialist Republic of Vietnam. Master Plan on Basic Geological Survey of Minerals through 2020-2030. In Decision 1388/2013/QD-TTg; Government of the Socialist Republic of Vietnam, Ed.; Government of the Socialist Republic of Vietnam: Hanoi, Vietnam, 2013.

45. Government of the Socialist Republic of Vietnam. Master Plan for Exploration, Mining, Processing and Use of Minerals as Construction Materials. In Decision 152/2008/QD-TTg; Government of the Socialist Republic of Vietnam, Ed.; Government of the Socialist Republic of Vietnam: Hanoi, Vietnam, 2008.

46. Amirtahmasebi, R.; Orloff, M.; Wahba, S.; Altman, A. Regenerating Urban Land: A Practitioner's Guide to Leveraging Private Investment; The International Bank for Reconstruction and Development (IBRD), Ed.; World Bank Group: Washington, DC, USA, 2016; p. 479.

47. Lyon Urban Planning Agency. How Can Urban Planning in Vietnam Be More Effective? Lyon Urban Planning Agency: Lyon, Franch, 2012; p. 22.

48. Reed, S.; Thinphanga, P. New risk and risk transfer: Climate and urban development case studies from Vietnam and Thailand. Proceedings of Viet'namese Cities Tomorro-Actions Today Conference, Hanoi, Vietnam, 30 October 2012.

49. Government of the Socialist Republic of Vietnam. Law on Environmental Protection. In 55/2014/QH13; Assembly, N., Ed.; Government of the Socialist Republic of Vietnam: Hanoi, Vietnam, 2014.

50. Government of the Socialist Republic of Vietnam. Policy for the Protection of the Rights of People in localites where minerals are exploited and processed and the protection of untapped mineral resources. In Decision 219/1999/QD-TTg; Office, P.M., Ed.; Government of the Socialist Republic of Vietnam: Hanoi, Vietnam, 1999.

51. United Nations Development Program. Terms of Reference: Rights of Local People in Mining Areas Identified in Legal Documents; UNDP: Hanoi, Vietnam, 2015. 
52. Government of the Socialist Republic of Vietnam. Land Law. In 45/2013/QH13; Assembly, N., Ed.; Government of the Socialist Republic of Vietnam: Hanoi, Vietnam, 2013.

53. Konrad-Adenauer-Stiftung e.V and the Association of Cities of Vietnam. People's Participation and Local Governance-Challenges and Opportunities for Municipalities; Konrad-Adenauer-Stiftung e.V and the Association of Cities of Vietnam: Hanoi, Vietnam, 2011; p. 41.

54. Clausen, A.; Vu, H.; Pedrono, M. An evaluation of the environmental impact assessment system in Vietnam: The gap between theory and practice. Environ. Impact Assess. Rev. 2011, 31, 136-143. [CrossRef]

55. Vietnam Ministry of Planning and Investment. Statistical Yearbook of Vietnam; Vietnam Ministry of Planning and Investment: Hanoi, Vietnam, 2014.

56. Tran, T.T.; Trinh, N.L.; Dung, N.V. Khoang San-Phat Trien-Moi Truong: Doi Chieu Giua ly Thuyet va Thuc Tien (Mining-Development_Environment: Comparing Theory and Practise); Pannature: Hanoi, Vietnam, 2012.

57. Oswald, K.; Riedel, W.; Schneider, P. Challenges and opportunities of aggregate mining in Hoa Binh province-The engineering perspective. In Proceedings of the Marex Side Event, Nexus Conference, Dresden, Germany, 16 May 2017.

58. Frey, M.; Spellerberg, I. Restoring the amenity and nature conservation values of gravel pits: An ecological restoration and community engagement approach. Aust. J. Environ. Manag. 2011, 18, 33-46. [CrossRef]

59. Corry, R.; Lafortezza, R.; Brown, R.D. Ecological functionality of landscapes with alternative rehabilitations of depleted aggregate sites. Int. J. Min. Reclam. Environ. 2010, 24, 216-232. [CrossRef]

60. Wells-Dang, A. The Political Influence of Civil Society in Vietnam. In Politics in Contemporary Vietnam; London, J.D., Ed.; Palgrave Macmillan: London, UK, 2014; pp. 162-183.

61. Jeong, Y.C. The Rise of State Corporatism in Vietnam. Contemp. Southeast Asia 1997, 19, 152-171. [CrossRef]

(C) 2019 by the authors. Licensee MDPI, Basel, Switzerland. This article is an open access article distributed under the terms and conditions of the Creative Commons Attribution (CC BY) license (http://creativecommons.org/licenses/by/4.0/). 